\title{
Amelanotic corneally displaced malignant conjunctival melanoma: a case report evaluated with impression cytology
}

\author{
Melanoma amelanótico conjuntival maligno deslocado sobre a córnea com citologia de impressão: \\ relato de caso
}

Jeison de Nadai Barros ${ }^{1}$, Márcia Motono 2,3 , Felipe D’Almeida Costa ${ }^{3}$, Marcelo Carvalho da Cunha², Martha Motono Chojniak ${ }^{3}$

\begin{abstract}
Here we describe the case of a 65-year-old Caucasian female who presented with an amelanotic malignant conjunctival melanoma and highlight the clinical and pathological features of this rare entity that displayed exclusive corneal invasive growth without evidence of conjunctival tumors other than primary acquired melanosis. Impression cytology aided in the initial diagnosis. The patient underwent surgical treatment. Histopathology and immunohistochemistry revealed an invasive amelanotic melanoma limited to the cornea and exhibiting S-100, Melan A, and HMB-45 positivity. The absence of pigmentation delayed early clinical detection and treatment. Awareness of this nonpigmented melanoma is important for early recognition and appropriate management.
\end{abstract}

Keywords: Melanoma/pathology; Conjunctival neoplasms; Eye neoplasms; Cy tological techniques; Diagnostic techniques, Ophthalmological; Humans; Female Aged; Case report

\section{RESUMO}

Os autores descrevem o caso de uma mulher branca de 65 anos que apresentava um melanoma amelanótico maligno conjuntival e destacam as características clínicas e patológicas desta entidade rara com crescimento invasivo exclusivo na córnea sem evidência de tumores na conjuntiva além de melanose adquirida primária sem pigmento. A citologia de impressão auxiliou no diagnóstico inicial. A paciente foi submetida a tratamento cirúrgico. A histopatologia e a imuno-histoquímica revelaram um melanoma amelanótico invasivo limitado sobre a córnea exibindo positividade para proteína S-100, Melan A e HMB-45. A ausência de pigmentação retardou sua identificação clínica e seu tratamento precoce. O conhecimento deste melanoma não pigmentado é importante para o reconhecimento precoce e a conduta apropriada.

Descritores: Melanoma/patologia; Neoplasias da túnica conjuntiva; Neoplasias oculares; Técnicas citológicas; Técnicas de diagnóstico oftalmológico; Humanos; Feminino; Idoso; Relato de caso

\section{INTRODUCTION}

Conjunctival melanoma shows considerable clinical variability This lesion usually presents as a pigmented or tan elevated lesion that can be located in any area of the conjunctiva. It may arise spontaneously (de novo), in a pre-existent nevus, or in association with primary acquired melanosis (PAM) with atypia ${ }^{(1)}$. Melanoma can extend from the conjunctiva onto the cornea or can be displaced and limited over the cornea without evidence of conjunctival tumors. The latter lesions comprise 5\% of all conjunctival melanomas and are called corneally displaced malignant conjunctival melanomas to describe their supposed conjunctival origin and actual corneal location (2)

The degree of pigmentation in melanomas depends on the amount of melanin in the tumor cells, macrophages, or extracellular matrix ${ }^{(3)}$. The corneally displaced melanoma is a rare disease, and the complete absence of intrinsic pigmentation is even more rare ${ }^{(2)}$.

\section{CASE REPORT}

The authors describe the case of a 65-year-old Caucasian female from Curitiba (Parana, Brazil). In June 2013, she was referred to one of the authors (M.M.) in São Paulo because of unresponsiveness to topical steroid treatment for a nonpigmented lesion located over her left cornea since 1 year. Although the lesion disturbed her blinking reflex, her vision remained unchanged because her left eye had amblyopia secondary to an untreated congenital cataract. She reported a history of Herpes simplex keratitis of the same eye since 2005, which had recurred several times, with the last episode in December 2012. On examination, the visual acuity of her left eye was count fingers. On examination, a fleshy, white, vascularized nodule with indistinct but well-outlined edges was observed on the temporal quadrant of the cornea (Figure 1A). Corneal opacities were observed in the inferior and nasal quadrants (Figure 1B). The nodule was surrounded by a margin of clear cornea and connected with superficial neovascular
Submitted for publication: August 21, 2013

Accepted for publication: October 24, 2013

Study carried out at Clínica de Olhos Dr. Moacir Cunha - São Paulo - SP (Brasil) and A.C. Camargo Cancer Center - São Paulo - SP, Brasil.

Laboratório de Citologia de Impressão, Clínica de Olhos Dr. Moacir Cunha - São Paulo (SP) - Brasil. 2 Clínica de Olhos Dr. Moacir Cunha.

${ }^{3}$ A.C. Camargo Cancer Center - São Paulo (SP) - Brasil.
Funding: No specific financial support was available for this study. Disclosure of potential conflicts of interest: J.N. Barros, None; M. Motono, None; F.D A. Costa, None; M.C. Cunha, None; M.M. Chojniak, None.

Correspondence address: Jeison de Nadai Barros. Al. Gabriel Monteiro da Silva, 1.000 - São Paulo (SP) - 01442-000 - Brazil - E-mail: jeisonbarros@hotmail.com 
vessels to the temporal limbus. The conjunctiva appeared normal without thickening or pigmentation. The right eye was normal, revealing an uncorrected distance visual acuity of 20/20 according to the Snellen chart. The intraocular pressure was $12 \mathrm{mmHg}$ in both eyes. There were no other abnormal findings, and no history of systemic disease was recorded. The patient was not undergoing any systemic or topical treatment, but she reported a positive family history of skin cancer. On the basis of slit-lamp examination, anterior segment ultrasound biomicroscopy, and the suspicion of a neoplastic lesion limited to the cornea, impression cytology (IC) was performed to confirm the diagnosis. Following induction of anesthesia with topical $0.5 \%$ proxymetacaine hydrochloride (Anestalcon ${ }^{\circledR} 0.5 \%$, Alcon, São Paulo,
Brazil), a membrane filter (Millipore HAWG01300, Bedford, EUA) was placed onto the corneal surface, gently pressed for $5 \mathrm{~s}$, and peeled off. Sampling was performed 3 consecutive times to increase the sensitivity of IC and access the deeper layers. The filters were immediately fixed in a solution containing glacial acetic acid, 37\% formaldehyde, and ethyl alcohol in a 1:1:20 volume ratio. All strips were processed with periodic acid-Schiff and Gill's hematoxylin stains. Glass slides were mounted with Entellan (Merck, Darmstadt, Germany) and cells were analyzed under light microscopy by an experienced professional (J.N.B)

IC samples (Figure 2) obtained from the nodule surface and the corneal opacities revealed abundant clusters of pleomorphic, atypi-
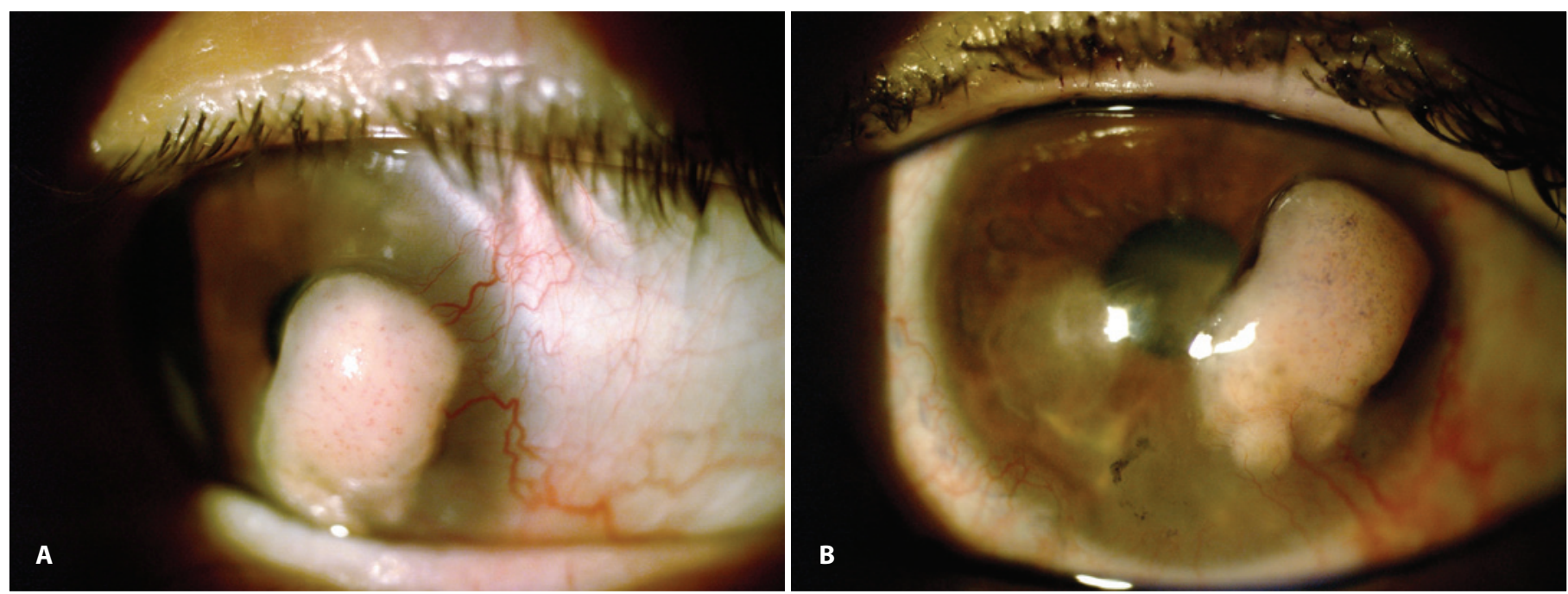

Figure 1. Clinical images obtained before surgery. A) Anterior segment photograph of the corneally displaced conjunctival melanoma obtained before surgery. B) A clinical image showing the temporal nodular amelanotic lesion and the corneal opacities in the inferior and nasal regions.

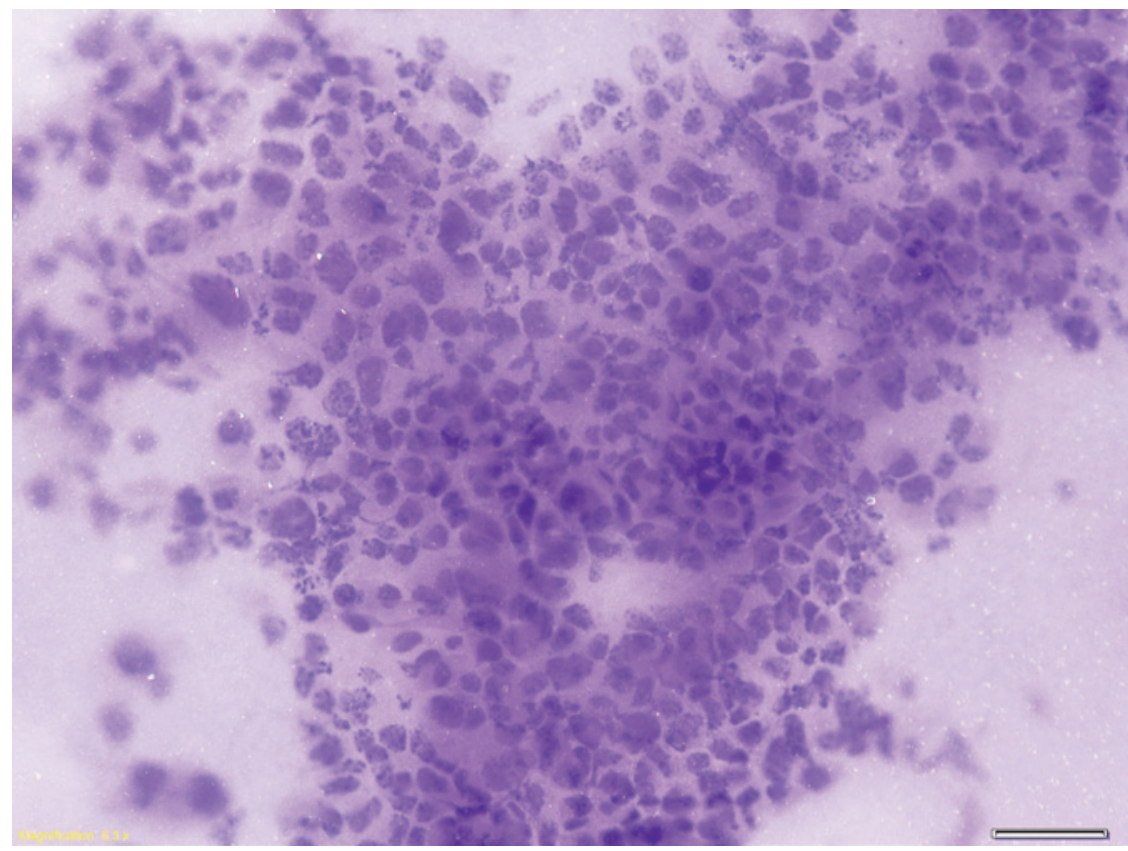

Figure 2. Findings of impression cytology. Impression cytology demonstrating clusters of pleomorphic, atypical, tumor-dissociated cells of different sizes and with anisokaryosis characterized by large and irregular nuclei in a cytomorphology not resembling epithelial cells (hematoxylin and eosin staining; original magnification, $\times 200$ ). 

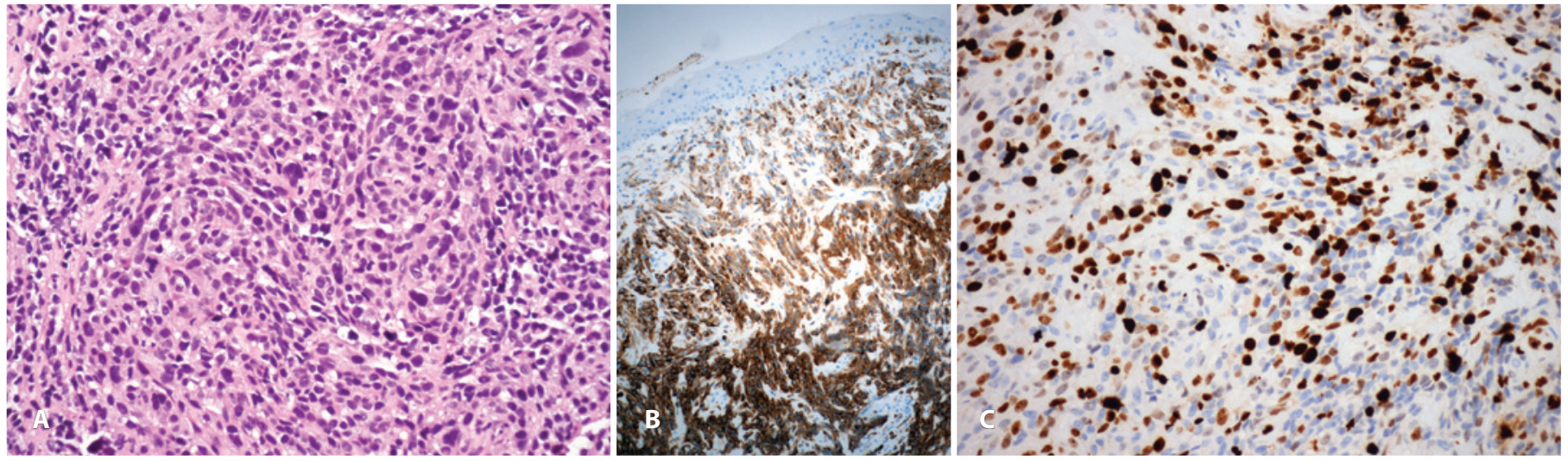

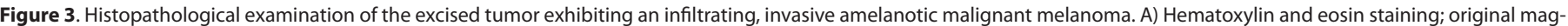
nification, $\times 200$. B) Positive staining for HMB-45 $(\times 100)$ and C) Ki-67 (×200).

cal, tumor-dissociated cells of different sizes with anisokaryosis characterized by large and irregular nuclei and occasionally prominent nucleoli. Some of the atypical cells were spindle-shaped. Melanin pigments were absent. Some non-neoplastic squamous epithelial cells were also observed. On the basis of cytomorphological findings, a tentative diagnosis of an amelanotic melanoma was made ${ }^{(4-5)}$

The initial surgical approach was complete resection of the corneal components with tumor-free margins, followed by conjunctival cryotherapy and alcohol corneal epitheliectomy. Histological studies were performed. All fragments of the 3-mm-thick tumor demonstrated (Figure 3) infiltrating intrastromal amelanotic malignant melanoma (MM) positive for the Melan A, S-100, and HMB-45 stains. Immunostaining for keratin and leukocyte-common antigen was negative. A high Ki-67 proliferation index of $40 \%$ was observed. Histology of the conjunctival specimens revealed PAM with atypia. One month after the surgery, the patient underwent adjunctive brachytherapy. Systemic review revealed the absence of any metastases.

\section{DISCUSSION}

The authors demonstrated that IC performed before treatment gave the first clue of melanoma diagnosis, which was subsequently confirmed by histopathology. Atypical melanocytes that have migrated to the epithelial surface can be detected by this technique, which is fast, noninvasive, inexpensive, and less distressing to the patient compared with surgical biopsy ${ }^{(4)}$. Amelanotic melanoma can be difficult to diagnose clinically, and IC can assist in making an initial diagnosis if its results are cautiously interpreted by a trained professional or under the guidance of an ocular pathologist ${ }^{(4-6)}$. Furthermore, incisional biopsy of this malignancy should be avoided because of the risk of local tumor dissemination ${ }^{(7)}$

The tumor in our patient was separated from the limbus by a margin of clear cornea. Several factors can potentially contribute to tumor development at this site. Most likely, atypical melanocytes associated with PAM, which typically spread within the conjunctival epithelium, migrate into the corneal epithelium. These cells then enter the vertical growth phase and give rise to an MM. Limbal melanocytes may also be carried along with epithelial cells that migrate from the limbal stem cell area to the basal layer of the corneal epithelium ${ }^{(2,8)}$. In the present case, the episodes of presumed keratitis may have played a role; this initial injury could have induced the migration of melanocytes into the cornea, followed by neoplastic transformation of these cells $s^{(2)}$. One case of corneally displaced malignant conjunctival melanoma secondary to Herpes simplex keratitis has previously been reported(2); however, it was lightly pigmented and differed from the lesion in our patient, which was completely nonpigmented.
Amelanotic MM can also arise in association with PAM. In our patient, histological examination revealed PAM with atypia in the conjunctiva, without clinically detectable conjunctival pigmentation. In some instances, PAM is subtle or not pigmented; therefore, it may not be clinically visible, leading to underestimation of frequency. The absence of pigmentation prevents early clinical detection of this variant of PAM and makes clinical diagnosis impossible; the diagnosis can only be established histopathologically. Awareness of this nonpigmented variety of PAM is crucial for early recognition and appropriate management of the associated melanoma ${ }^{(3)}$. The aim of treatment should be to eradicate the tumor, prevent local recurrence, and prevent distant metastasis and death ${ }^{(7)}$

Amelanotic MM is an extremely uncommon tumor that primarily affects Caucasian adults. It is important to examine the entire conjunctiva, including eversion of the eyelids, to exclude PAM and multifocal melanoma ${ }^{(9)}$, which can accompany a corneal tumor ${ }^{(2)}$. A corneal MM may vary in appearance, from a nodular and amelanotic lesion, as observed in our patient, to a flat and pigmented lesion ${ }^{(10)}$ or a corneal stromal opacity secondary to trauma ${ }^{(8)}$ or continuous exposure to plastics fumes at work ${ }^{(9)}$.

In conclusion, the findings of this case indicate that awareness of this nonpigmented melanoma is important for early recognition and appropriate management.

\section{REFERENCES}

1. Shields CL, Shields JA. Tumors of the conjunctiva and cornea. Surv Ophthalmol. 2004; 49(1):3-24

2. Tuomaala S, Aine E, Saari KM, Kivela T. Corneally displaced malignant conjunctival melanomas. Ophthalmology. 2002;109(5):914-9.

3. Jay V, Font RL. Conjunctival amelanotic malignant melanoma arising in primary acquired melanosis sine pigmento. Ophthalmology. 1998;105(1):191-4.

4. Paridaens AD, McCartney AC, Curling OM, Lyons CJ, Hungerford JL. Impression cyto logy of conjunctival melanosis and melanoma. Br J Ophthalmol. 1992;76(4):198-201.

5. Keijser S, Missotten GS, De Wolff-Rouendaal D, Verbeke SL, Van Luijk CM, Veselic Charvat $\mathrm{M}$, et al. Impression cytology of melanocytic conjunctival tumours using the Biopore membrane. Eur J Ophthalmol. 2007;17(4):501-6.

6. Santo RM, Bordon PB, Barros J de N, Schellini SA, Erwenne CM. Tumores da superfície ocular. In: Gomes JA, Alves MR, editores. Superfície ocular: córnea, limbo, conjuntiva, filme lacrimal. 2a ed, Rio de Janeiro: Cultura Médica; 2011. p.141-70.

7. Lim L, Madigan MC, Conway RM. Conjunctival melanoma: a review of conceptual and treatment advances. Clin Ophthalmol. 2013;6:521-31.

8. Naseri A, Char DH, Howes E, Paglen P. Amelanotic corneal melanoma after a blast injury. Am J Ophthalmol. 2001;131(2):259-60.

9. Paridaens AD, MCCartney AC, Hungerford JL. Multifocal amelanotic conjunctival melanoma and acquired melanosis sine pigmento. Br J Ophthalmol. 1992;76(3):163-5.

10. Paridaens ADA, Kirkness CM, Garner A, Hungerford JL. Recurrent malignant melanoma of the corneal stroma: a case of 'black cornea'. Br J Ophthalmol. 1992;76(7): 444-6. 